\title{
Complement C3d
}

National Cancer Institute

\section{Source}

National Cancer Institute. Complement C3d. NCI Thesaurus. Code C154099.

Complement C3d (302 aa, 34 kDa) is encoded by the human C3 gene. This protein is involved in the promotion of B-cell and complement activation. 